\title{
KRITIK SOSIAL PADA KUMPULAN CERPEN KARYA PESERTA LOMBA MENULIS CERITA ANAK
}

\author{
Rachmawati Saeful ${ }^{1}$, Seni Apriliya ${ }^{2}$ \\ Universitas Pendidikan Indonesia \\ E-mail: rachmawatisaeful@upi.edu¹, seni_apriliya@upi.edu²
}

\begin{abstract}
Abstrak: Sastra merupakan teks yang bisa terbentuk dari gambaran sosial masyarakat sebagai bahan refleksi dari kehidupan manusia. Penelitian ini mengungkap permasalahan mengenai unsur struktural dan kritik sosial yang terdapat pada kumpulan cerpen karya peserta LMCA tahun 2011. Problematika yang ada di masyarakat dituangkan oleh pengarang melalui karya sastra tersebut sebagai media kritik. Tujuan penelitian ini untuk mendeskripsikan: (1) unsur struktural yang membangun naskah cerpen LMCA tahun 2011; dan (2) kritik sosial yang terdapat pada naskah cerita anak tersebut. Penelitian ini menggunakan metode penelitian deskriptif kualitatif dengan pendekatan struktural dan pendekatan sosiologi sastra. Strategi yang digunakan yaitu analisis isi (content analysis). Sumber data penelitian yaitu Kumpulan Naskah Cerpen terbaik Lomba Menulis Cerita Anak (LMCA) tahun 2011. Dari 15 naskah LMCA tahun 2011, terdapat 7 naskah yang di dalamnya mengungkap kritik sosial. Teknik pengambilan subjek penelitian ini menggunakan teknik purposive sampling. Hasil penelitian yaitu: (1) secara struktural, setiap naskah cerpen memiliki unsur intrinsik dan ekstrinsik yang berbeda-beda meliputi alur, tokoh, latar, tema, amanat, sudut pandang, gaya bahasa, latar belakang pengarang, kondisi sosial budaya, dan tempat cerpen dikarang; (2) secara sosiologi, ketujuh naskah cerpen mengungkap enam masalah sosial yang dikritik yaitu masalah lingkungan, gender, ekonomi, pendidikan, kebiasaan/kebudayaan masyarakat, dan sikap diskriminasi. Kesimpulan penelitian ini adalah bahwa hasil analisis kritik sosial terhadap kumpulan cerpen tersebut mengungkap tentang kritik pengarang terhadap sikap manusia yang menyimpang.
\end{abstract}

Kata Kunci: kritik sosial, naskah cerpen, sosiologi sastra

\section{SOCIAL CRITICISM ON A COLLECTION OF SHORT STORY BY PARTICIPANTS OF CHILDREN'S STORY WRITING COMPETITION}

\begin{abstract}
Literature is a text that can be formed from the social picture of society as a reflection of human life. This study uncovers problems regarding structural elements and social criticism contained in a collection of short stories by LMCA participants in 2011. The problems that exist in society are expressed by the authors through these literary works as a medium of criticism. The purpose of this study is to describe: (1) the structural elements that build the 2011 LMCA short story script; and (2) social criticism contained in the children's story script. This study uses a qualitative descriptive research method with a structural approach and a sociological approach to literature. The strategy used is content analysis. The source of the research data is the collection of the best short stories in the Children's Story Writing Competition (LMCA) in 2011. Of the 15 LMCA manuscripts in 2011, there are 7 manuscripts which reveal social criticism. The technique of taking the subject of this research used purposive sampling technique. The results of the study are: (1) structurally, each short story script has different intrinsic and extrinsic elements including plot, character, background, theme, mandate, point of view, language style, author background, socio-cultural conditions, and the place of the short story composed; (2) sociologically, the seven short stories reveal six social problems that were criticized, namely environmental issues, gender, economy, education, community
\end{abstract}

BASASTRA Jurnal Bahasa, Sastra, dan Pengajarannya

Volume 9 Nomor 2, Oktober 2021, P-ISSN 2302-6405, E-ISSN 2714-9765 
habits/culture, and attitudes of discrimination. The conclusion of this study is that the results of the analysis of social criticism of the collection of short stories reveal the author's criticism of deviant human attitudes

Keywords: social criticism, short story script, sociology of literature

\section{PENDAHULUAN}

Sastra merupakan teks yang selalu berhubungan dengan pengarang dan lingkungan karena terbentuk dari gambaran sosial masyarakat pada waktu tertentu bersumber dari masalahmasalah sosial yang terjadi sebagai bahan refleksi dari kehidupan manusia. Karya sastra merupakan hasil imajinasi dan kreativitas pengarang yang dipengaruhi oleh banyak pengalaman dari lingkungan hidupnya sehingga karya sastra tidak hanya lahir dari kekosongan budaya dan sosial tetapi juga refleksi dari masyarakat (Damono, 2010., Swingewood, Al., \& Laurenson, 1972). Oleh karenanya, sastrawan dengan kehidupan tidak dapat dipisahkan karena karya sastra yang diciptakan terinspirasi dari problematika yang ada di masyarakat.

Menurut Saini (1986) tujuan sastra untuk memperluas, memperdalam, dan memperjernih penghayatan pembaca terhadap salah satu sisi kehidupan yang disajikannya. Kehidupan orang dewasa akan berbeda dengan anak-anak. Maka, ada karya sastra yang secara khusus untuk dunia anak, dibaca anak, tetapi masih dalam bimbingan orang dewasa. Sastra anak merupakan sebuah karya sastra berupa buku bacaan yang isi dan bahasanya berkolerasi khas dengan dunia anakanak karena dikonsumsi oleh anak- anak sesuai perkembangan intelektual dan emosionalnya (Witakania, 2008., Sarumpaet, 2010., \& Kurniawan, 2013). Sependapat dengan Nurgiyantoro (2013: 12) mendefinisikan sastra anak sebagai karya sastra yang menempatkan sudut pandang anak sebagai pusat penceritaan. Karya sastra terdiri atas tiga genre yaitu prosa, puisi, dan drama. Esensi dari tujuan pembelajaran sastra yaitu kegiatan apresiasi sastra. Menurut Effendi (1973:7) apresiasi sastra adalah suatu kegiatan menggauli sastra dengan sungguh-sungguh hingga tumbuh pengertian, penghargaan, kepekaan pikiran kritis, dan kepekaan perasaan yang baik terhadap cipta sastra. Teks sastra yang dapat diapresiasi salah satunya prosa anak jenis cerpen (cerita pendek). Menurut Rokhmansyah (2014:2), seorang pengarang dapat menyampaikan pandangannya mengenai kehidupan sekitar melalui cerpen.

Direktorat Jenderal Pendidikan Dasar menyelenggarakan sebuah program yang mengandung apresiasi karya sastra. Kegiatan tersebut yaitu Lomba Menulis Cerita Anak (LMCA). Kegiatan tersebut diadakan karena melihat rendahnya minat dan kemampuan "baca-tulis" siswa sehingga dengan adanya kegiatan ini diharapkan dapat menjadi daya dorong 
siswa berkompetisi menuangkan hasil pemikirannya, hasil bacaannya, dan pengalamannya untuk kemudian mengekspresikannya dalam karya tulis ilmiah khususnya cerita anak. Dari ajang Lomba Menulis Cerita Anak (LMCA) tahun 2011, terdapat 15 Karya Naskah Terbaik karya pengarang anak kelahiran tahun 2000-2003 dengan tema kejujuran dan kedisiplinan. Kumpulan naskah tersebut akan dijadikan sumber data penelitian.

Alasan memilih naskah LMCA tahun 2011 karena sejauh ini belum ada penelitian yang menganalisis kritik sosial Naskah LMCA tahun 2011. Selain itu, kumpulan naskah cerita anak ini memiliki relevansi dengan pembelajaran Bahasa Indonesia di Sekolah Dasar dilihat dari adanya materi sastra salah satunya teks cerita fiksi pada KTSP dan Kurikulum 2013. Kumpulan naskah cerita anak ini juga membantu pengajaran sastra secara utuh karena memberikan manfaat di antaranya membantu keterampilan berbahasa, meningkatkan pengetahuan budaya, mengembangkan cipta dan rasa, serta menunjang pembentukan watak (Rahmanto, 1988).

Kritik sosial akan muncul ketika masyarakat merasa ada yang tidak beres dalam kehidupan sosialnya sehingga tidak puas pada kenyataan yang ada. Seperti yang dirasakan oleh para pengarang LMCA tahun 2011 menuangkan kritikannya melalui cerpen sebagai bentuk protes dan ungkapan perasaan. Hal itu menunjukkan bahwa masih ada ketimpangan-ketimpangan sosial yang perlu dibenahi. Sehingga urgensi penelitian ini dilakukan untuk mengetahui apa saja kritikan terhadap permasalahan sosial pada kumpulan naskah LMCA tahun 2011. Oleh karena itu, untuk mengungkap kritik sosial dalam isi naskah LMCA tahun 2011 dapat dianalisis menggunakan pendekatan sosiologi sastra. Sosiologi sastra yaitu sebuah pendekatan untuk menyatakan adanya keterkaitan antara karya sastra dengan masyarakat. Adapun pendekatan struktural digunakan sebagai pendekatan penunjang karena untuk mengungkap kritik sosial perlu memahami unsur cerita baik intrinsik maupun ekstrinsik.

Tentunya karya sastra yang baik mengandung masalah sosial di dalamnya. Sastra bukan hanya media hiburan tetapi juga berfungsi sebagai media kritik. Hal ini berkaitan dengan fungsi sastra sebagai "dulce et utile" yang artinya "bermanfaat dan menyenangkan" (Horace dalam Wellek, R., \& Warren, 1989:25., Teeuw, 1984:51). Melalui konsep ini, karya sastra dipandang sebagai media menyampaikan kritik sosial dengan cara menghibur dan menyenangkan.

Didukung oleh beberapa penelitian terdahulu yang mengungkap kritik sosial dari naskah cerpen dan novel di antaranya yaitu, Ardiyanti, (2017) yang menganalisis cerpen Jepang dalam skripsinya menggunakan pendekatan sosiologi sastra yang dilatarbelakangi oleh Motojiro Kajii yang membayangkan di bawah pohon 
sakura terdapat mayat atau bangkai yang terkubur. Mengandung kritik sosial dengan mengkaji teori strukturalnya memuat tema, alur, latar, sudut pandang, dan amanat. Penelitian Yulianto (2017) yang menganalisis kritik sosial dari dua cerpen. Cerpen tersebut yaitu Angin Besar Menggerus Ladang-ladang Kami karya Hajriansyah dan Hitam Putih Kotaku karya Rismiyana. Menggunakan pendekatan sosiologi sastra, kedua cerpen tersebut mengandung kritik sosial terhadap masalah perusakan alam, pergaulan bebas, dan sikap berkesenian.

Penelitian (Pratiwi, Y. I., Harun, M., \& Herman, 2018) pada novel Tanah Surga Merah karya Arafat Nur mengenai fenomena penyimpangan sosial seperti pelanggaran norma masyarakat di Aceh menggunakan pendekatan sosiologi sastra dan struktural sehingga mengungkap kritik sosial diantaranya moral, politik, seks, ekonomi, kekerasan, pendidikan, agama, gender, teknologi, dan narkoba. Penelitian (Puspita, A. C., Suwandi, S., \& Hastuti, 2018) terhadap novel Negeri di Ujung Tanduk mengungkap kritik sosial dengan hanya menggunakan pendekatan sosiologi sastra yang didalamnya mengandung banyak kontroversi di kehidupan masyarakat. Sedangkan penelitian (Nandasari, V., \& Hasanah, 2020) pada Novel Orangorang Biasa karya Andrea Hirata mengungkap banyaknya kepincangan pada pemerintah dan masyarakat seperti birokrasi. Walaupun penelitiannya tidak menggunakan pendekatan sosiologi sastra namun masih sama mengenai kritik sosial. Kemudian ada juga penelitian Lestari, S., Rakhmawati, A., dan Rohmadi, (2016) yang menganalisis cerpen pilihan Kompas tahun 2014 dari sudut pandang teori struktural memuat unsur intrinsik dan ekstrinsik sampai menganalisis relevansi pembelajaran sastra di sekolah dasar. Keenam penelitian tersebut sangat relevan dengan penelitian yang akan dilakukan. Hal itu karena menggunakan metode yang sama yaitu deskriptif kualitatif dan juga menggunakan pendekatan struktural dan pendekatan sosiologi sastra.

Dari latar belakang di atas, dapat diuraikan rumusan masalah penelitian ini diantaranya yaitu (a) bagaimana unsur struktural yang membangun naskah cerita anak tersebut? dan (b) apa saja kritik sosial yang terdapat pada naskah cerita anak tersebut? Tujuan penelitian ini yaitu untuk mendeskripsikan struktur yang membangun naskah cerita anak tersebut serta mengungkap kritik sosial pada naskah cerita anak dari data LMCA tahun 2011. Sehingga peneliti tertarik untuk mengambil judul penelitian "Kritik Sosial pada Kumpulan Cerpen Karya Peserta Lomba Menulis Cerita Anak Tahun 2011". Manfaat dari penelitian ini baik secara teoretis maupun praktis selain sebagai informasi, diharapkan dapat menjadi inspirasi, meningkatkan 
moral, dan memperbaiki berbagai permasalahan sosial sehingga ada kesadaran untuk menjadikan kehidupan lebih baik.

\section{METODE}

Metode penelitian yang digunakan yaitu deskriptif kualitatif dengan pendekatan struktural dan pendekatan sosiologi sastra. Penelitian kualitatif digunakan untuk mendapatkan detail-detail yang rumit tentang fenomena seperti perasaan, proses pikiran, dan emosi yang sulit untuk dipelajari melalui metode yang lebih konvensional (Strauss \& Corbin, 1998; Creswell, 2015). Pendekatan struktural menurut Sangidu (Lestari, S., Rakhmawati, A., \& Rohmadi, 2016) di mana karya sastra dipandang sebagai suatu struktur terdiri dari beberapa unsur yang berkaitan satu sama lain. Pendekatan sosiologi sastra menurut (Tube, 2018) yaitu pendekatan yang mempertimbangkan sastra dari segi kemasyarakatan. Strategi yang digunakan yaitu analisis isi (content analysis).

Sumber data penelitian yaitu Kumpulan Naskah Cerpen terbaik Lomba Menulis Cerita Anak (LMCA) tahun 2011. Menurut (Ratna, 2006) dalam ilmu sastra, sumber datanya adalah karya naskah, data penelitiannya dapat berupa kata-kata, kalimat, dan wacana. Data penelitian ini adalah bagian-bagian naskah cerpen yang mengandung unsur kritik sosial baik dalam bentuk dialog, frasa, klausa, kalimat, maupun paragraf. Subjek penelitian adalah benda, hal, atau orang tempat variabel melekat dan yang dipermasalahkan dalam penelitian (Suandi, 2008). Dari 15 naskah cerpen, yang dijadikan subjek penelitian ini yaitu sebanyak 7 naskah cerpen LMCA tahun 2011 dengan objek penelitian fokus pada kritik sosial yang terdapat pada ketujuh naskah cerpen tersebut. Teknik pengambilan subjek penelitian dengan purposive sampling, yaitu pengambilan data yang dilakukan dengan cara memilih informan yang dianggap mengetahui informasi dan masalahnya secara mendalam serta dapat dipercaya untuk menjadi sumber data yang mantap (Sutopo, 2002).

Teknik pengumpulan data dengan menganalisis dokumen memuat proses membaca berulang secara intensif, mencari bagian cerpen yang menggambarkan kritik sosial dari kumpulan naskah cerpen terbaik LMCA tahun 2011, mengidentifikasi peristiwa yang mengandung kritik sosial, dan menandai data yang mengandung kritik sosial. Selain itu, melakukan diskusi dengan dosen untuk mendapatkan informasi yang lebih akurat.

Langkah-langkah teknik analisis data dilakukan seperti menurut (Miles, M. B. \& Huberman, A. M., 1984) yaitu analisis interaktif yang meliputi pengumpulan data, reduksi data, penyajian data, dan penarikan simpulan. Pengecekan pengabsahan data menggunakan teknik triangulasi data. Menurut (Moleong, 2014) triangulasi adalah teknik pemeriksaan 
keabsahan data yang memanfaatkan sesuatu yang lain di luar data untuk keperluan pengecekan atau sebagai pembanding terhadap data itu.

\section{HASIL DAN PEMBAHASAN}

Penelitian ini mengkaji naskah cerpen karya peserta LMCA tahun 2011 menggunakan pendekatan struktural dan sosiologi sastra. Ketimpangan-ketimpangan yang terjadi di masyarakat dituangkan dalam karya sastra melalui kritikan. Setelah mengkaji dari 15 naskah peserta LMCA ini terdapat 7 naskah yang di dalamnya mengungkap kritik sosial. Naskah tersebut di antaranya Cerita Pohon Jati karya Sarita, Taat Membawa Selamat karya Probolestari, Jangan Pernah Menyesal Bertindak Jujur karya Alexandra, Disiplin Kunci Keberhasilan karya Saputra, Pensil Warna untuk Adik karya Irene, Sepatu Kiki karya Mardhotillah, dan Ketidakjujuran Nanda karya Kristianti. Ketujuh naskah menunjukkan ungkapan perasaan para pengarang yang menggambarkan kritik sosial.

Berdasarkan hasil analisis, penelitian ini mendeskripsikan: (1) secara struktural meliputi unsur intrinsik dan ekstrinsik; dan (2) secara sosiologi memuat beberapa kritik sosial. Berikut deskripsi hasil dan pembahasan dari penelitian ini.

\section{Analisis Unsur Intrinsik Kumpulan} Naskah Cerpen LMCA Tahun 2011

Menurut (Ratna, 2014) menganalisis karya sastra dengan pendekatan struktural harus memuat tema, tokoh, gaya bahasa, alur, dan sebagainya. Sebelum mengungkap kritik sosial dari naskah cerpen yang dikaji harus memahami struktur intrinsik dan ekstrinsik yang akan dijelaskan melalui deskripsi sebagai berikut.

\section{Plot/Alur}

Alur pada naskah Cerita Pohon Jati yaitu alur maju. Naskah ini menceritakan keresahan penghuni hutan akan pemburuan dan penebangan liar. Dari sana ada kerja sama antara hewan dan burung untuk menyelamatkan pohon jati.

Alur pada naskah Taat Membawa Selamat yaitu alur maju mundur. Naskah ini menceritakan ketidakdisiplinan dan mengabaikan peraturan dalam berkendara.

Alur pada naskah Jangan Pernah Menyesal Bertindak Jujur yaitu maju. Naskah ini menceritakan seseorang yang angkuh dan gampang menuduh. Sampai orang itu sadar bahwa mengakui kesalahan merupakan bagian dari sikap jujur.

Alur pada naskah Disiplin Kunci Keberhasilan yaitu maju. Naskah ini menceritakan seorang anak yang hobi bermain sepak bola tapi mempunyai kebiasaan tidak disiplin dan menganggap wajar karena dirinya laki-laki.

Alur pada naskah Pensil Warna untuk Adik yaitu maju mundur. Naskah ini menceritakan anak dari keluarga tidak mampu dituduh mencuri pensil 
warna dan terbukti tidak mencuri karena seseorang menceritakan kejadian yang sebenarnya.

Alur pada naskah Sepatu Kiki yaitu maju mundur. Naskah ini menceritakan bagaimana kehidupan Kiki dari sudut pandang sepatu sebagai tokoh sampingan.

Alur pada naskah Ketidakjujuran Nanda yaitu maju. Naskah ini menceritakan seorang siswa yang curang saat ditugaskan membuat cerpen dengan menyontek dari majalah dan berakhir meminta maaf.

\section{Tokoh \& Penokohan}

Tokoh pada naskah Cerita Pohon Jati yaitu pohon jati, burung kakak tua, burung beo, kelinci, rusa, semut, kelelawar, dan para penebang (manusia).

Tokoh pada naskah Taat Membawa Selamat yaitu Sen, Ayah dan Ibu Sen, Mas Galih, Bulik, Om Sulaiman, Kara, Mas Bayu, polisi, dua korban kecelakaan, supir dan kenek bus, petugas medis, penumpang bus, dan saksi.

Tokoh pada naskah Jangan Pernah Menyesal Bertindak Jujur yaitu Lisya, Felis, Ayah Lisya, Pak Rustaman, dan Dyan.

Tokoh pada naskah Disiplin Kunci Keberhasilan yaitu Andi, Ayah dan Ibu Andi, Bima, Ayah Bima dan Coach Dani.

Tokoh pada naskah Pensil Warna untuk Adik yaitu Wirya, Aida, Agung, Nur, Nenek dan Ibu Wirya,
Bagas, Brian, Bu Sri, Pak Budi, dan penjaga koperasi.

Tokoh pada naskah Sepatu Kiki yaitu Kiki, Sepatu (sebagai tokoh sampingan), Ayah, Ibu, Adik, dan Kakaknya Kiki, dan Bu Farid.

Tokoh pada naskah Ketidakjujuran Nanda yaitu Kristi, Putri, Pak Sarman, Nanda, dan Ibunya Kristi.

Berikut ini kutipan dari tokoh utama dari setiap naskah cerita tersebut.

"Siapa yang tega menebang pohon di lereng gunung?" Bu Jati. (Sarita, 2011:2).

\section{"itukah prosedur di TKP yang} harus dilakukan?” Sen. (Probolestari, 2011:11).

“...akan kupecat supir-supir tidak berguna itu!" Lisya. (Alexandra, 2011:17).

"masih capek, Coach. Anak lain saja...” Andi. (Saputra, 2011:27).

"Bisa dibilang akulah yang paling miskin..." Wirya. (Irene, 2011:34).

"...Aku sudah berdosa, mencuri uang dari wali kelasku” Kiki. (Mardhotillah, 2011:98).

"Aku juga memberi saran supaya tidak mengulangi..." Kristi. (Kristianti, 2011:113).

\section{Latar}

Latar pada kumpulan naskah cerpen LMCA tahun 2011 diklasifikasikan menjadi tiga, yaitu latar tempat, latar waktu, dan latar suasana. 


\section{Latar Tempat}

Latar tempat pada naskah Cerita Pohon Jati yaitu hutan dan lereng gunung.

"Oh mereka berasal dari lereng gunung, mereka pindah kesini karena..."-Seluruh hewan-hewan di hutan pun berkumpul dan membuat suatu rencana. (Sarita, 2011:2-3).

Latar tempat pada naskah Taat Membawa Selamat yaitu rumah Bulik di Yogyakarta, rumah Sen di Kebumen, Rumah Eyang, dapur, toko buku, pom bensin, lampu merah, terminal Purworejo, pos keluar bus umum, dan rumah sakit.

Menginap di rumah Bulik Pratiwi.-rumah kami di Kebumen.Tiap di rumah Eyang ada acara keluarga.-bahkan membantu ibu di dapur-isi penuh di pom bensin.sampai di lampu merah depan pintu keluar terminal Purworejo.-bertaruh nyawa di Rumah Sakit (Probolestari, 2011:8-12).

Latar tempat pada naskah Jangan Pernah Menyesal Bertindak Jujur yaitu kamar, rumah, gudang, pohon rindang, tengah lapangan.

Melalui celah-celah tirai jendela kamarku.-teriakku yang langsung berlari ke pelukan Ayah begitu aku tiba di rumah.-ketika Dyan henda merapikan gudang tiba-tiba tampak pantulan cahaya...-kami berteduh di sebuah pohon rindang-Aku berjalan ke tengah lapangan.... (Alexandra, 2011:17-22).
Latar tempat pada naskah Disiplin Kunci Keberhasilan yaitu lapangan sepak bola dan sekolah.

"aku capek, Yah. Di sekolah tadi pelajarannya sulit-sulit".-karena terlalu lelah, aku meninggalkan lapangan dan duduk di pinggir lapangan (Saputra, 2011:27).

Latar tempat pada naskah Pensil Warna untuk Adik yaitu rel kereta, jalanan, sekolah, persimpangan, koperasi sekolah, dan kantor guru.

Aku berjalan menyusuri rel kereta api di pagi dingin.-hingga sampai di persimpangan.-di sekolah, aku tergolong anak yang cukup bisa mengikuti pelajaran.-pensil warna itu di koperasi sekolah.-"Wirya, ayo ikut Ibu ke kantor”. (Irene, 2011:35-37).

Latar tempat pada naskah Sepatu Kiki yaitu sekolah, rumah, ruang guru, terminal, toilet, dan trotoar.

Sesampainya di rumahnya segera aku dimandikan, lalu dijemur.di hari lain ia pergi ke terminal,..sesampainya di sekolah, ia tetap berusaha terlihat ceria.-sepulang sekolah, ia pergi ke ruang guru. Wali kelasnya sedang pergi ke toilet.-ia mengajakku duduk-duduk di trotoar (Mardhotillah, 2011:96-98).

Latar tempat pada naskah Ketidakjujuran Nanda yaitu sekolah dan rumah

Kriling... bel tanda masuk sekolah berbunyi. Aku dan temanteman bergegas masuk kelas dan duduk,..-setelah sampai di rumah berganti baju, dan istirahat sejenak,... (Kristianti, 2011:110-111). 
Latar Tempat Berdasarkan Arah Mata Angin

Di sebelah barat buku-buku tentang komputer, ada komik dan buku....-dari sebelah barat pos keluar sebuah bis... (Probolestari, 2011:8-11).

\section{Latar Waktu}

(1) Pagi hari

Latar waktu yang menunjukkan pagi terdapat pada naskah Cerita Pohon Jati, Disiplin Kunci Keberhasilan, Pensil Warna untuk Adik, Sepatu Kiki, dan Ketidakjujuran Nanda. Salah satu kutipannya yaitu:

Aku terbangun, sinar matahari tepat menyinari wajahku.-"selamat pagi, Bu Jati” kata burung kakak tuaSetiap pagi memang banyak burung yang bertengger di dahanku. (Sarita, 2011:2).

\section{(2) Siang hari}

Latar waktu yang menunjukkan siang hari terdapat pada naskah Jangan Pernah Menyesal Bertindak Jujur, dan Disiplin Kunci Keberhasilan. Salah satu kutipannya:

Siang ini terik matahari yang panas membakar kulit kami.-"masa anak bos dibiarkan menunggu berpanas-panasan begini sih?" (Alexandra, 2011:17).

(3) Sore hari

Latar waktu yang menunjukkan sore hari pada naskah Jangan Pernah Menyesal Bertindak Jujur yaitu:
Pada suatu sore ketika Dyan hendak merapikan gudang tiba-tiba tampak pantulan cahaya keemasan dari... (Alexandra, 2011:20).

(4) Malam hari

Latar waktu yang menunjukkan malam hari terdapat pada naskah Taat Membawa Selamat, Disiplin Kunci Keberhasilan, dan Sepatu Kiki. Salah satu kutipannya:

Malam mulai larut, namun aku belum bisa tidur.-malam ini terjadi saat kami sampai di lampu merah depan pintu... (Probolestari, 2011:811).

(5) Dini hari

Latar waktu yang menunjukkan dini hari pada naskah Taat Membawa Selamat:

Waktu menunjukkan pukul
01.00 dini hari. (Probolestari,
2011:13).

(6) Latar waktu berdasarkan posisi tata surya (bulan)

Posisi atau datangnya bulan dikutip pada naskah Jangan Pernah Menyesal Bertindak Jujur menunjukkan malam hari.

Cahaya bulan menyusup
remang-remang melalui celah-celah
tirai jendela kamarku. Seolah ingin
bersaing dengan cahaya lampu yang
menerangi kamar ini. (Alexandra,
2011:17).


(7) Latar waktu berdasarkan iklim

Kondisi iklim atau cuaca yang panas pada naskah Pensil Warna untuk Adik menunjukkan waktu siang hari. Terdapat pada kutipan berikut:

Di jam istirahat yang cukup panas, aku duduk sendirian di dalam kelas sambil melamun. (Irene, 2011:35).

(8) Latar waktu berdasarkan waktu ibadah salat

Waktu ibadah shalat subuh pada naskah Taat Membawa Selamat menunjukkan waktu menjelang pagi hari. Kutipannya sebagai berikut:

Pagi-pagi setelah shalat subuh Mas Galih memeriksa kondisi motor.

Sudah jadi kebiasaan di keluarga kami,... (Probolestari, 2011:811).

\section{Latar Suasana}

Latar suasana pada naskah Cerita Pohon Jati yaitu senang, ramai, dan sedih.

Aku sangat senang karena aku bisa bercanda dengan mereka"mengapa ramai sekali pagi ini?", tanyaku heran-Aku sangat sedih mendengarnya, tidak tahukah mereka bahwa hutan yang ada di lereng gunung dilindungi. (Sarita, 2011:2-3).

Latar suasana pada naskah Taat Membawa Selamat yaitu sedih dan panik.

Keluarga mereka pasti sedih dan panik. (Probolestari, 2011:8-12).
Latar suasana pada naskah Jangan Pernah Menyesal Bertindak Jujur yaitu kesal.

"huh! Awas saja, nanti kalau sudah sampai di rumah,..."-“iya, nih! Bisa mati gosong aku!"-"sudah kubilang!...” (Alexandra, 2011:17-22).

Latar suasana pada naskah Disiplin Kunci Keberhasilan yaitu tegang dan senang.

Saat pengumuman pun tiba. Hatiku berdebar-debar karena takut bila aku tidak lolos.-“aku lolos!”, teriakku sambil menghadap ke tempat duduk ayah di tribun. (Saputra, 2011:28-30).

Latar suasana pada naskah Pensil Warna untuk Adik yaitu gaduh dan tegang.

"alah, temanmu itu dah nyolong punyanya temannya sendiri, malah kamu belain"-"sudah, sudah, jangan berkelahi di dalam kelas!"suasana cukup tegang,..." (Irene, 2011:36-38).

Latar suasana pada naskah Sepatu Kiki yaitu terharu, panik, sedih, dan gelisah.

Aku melihatnya kadang kerepotan mengurus dua adiknya yang masih kecil.-ia panik, lalu buru-buru memasukkan uang tersebut...-raut mukanya tampak sedih dan gelisah. (Mardhotillah, 2011:97-100).

Latar suasana pada naskah Ketidakjujuran Nanda yaitu ramai dan serius.

Kelas menjadi ramai,-“kalian tampak serius...” (Kristianti, 2011:110-113). 
Tema

Tema pada naskah Cerita Pohon Jati, Jangan Pernah Menyesal Bertindak Jujur, Pensil Warna untuk Adik, Sepatu Kiki, dan Ketidakjujuran Nanda yaitu kejujuran. Sedangkan tema pada naskah Taat Membawa Selamat, Disiplin Kunci Keberhasilan yaitu kedisiplinan.

\section{Amanat}

Amanat yang dapat diambil dari naskah Cerita Pohon Jati yaitu bersikaplah jujur dan saling bekerja sama. Kejujuran mampu mengatasi masalah asalkan pantang menyerah sebelum mencoba.

"sekarang kita harus selalu jujur, saling bekerja sama..” (Sarita, 2011:4).

Amanat yang dapat diambil dari naskah Taat Membawa Selamat yaitu belajar untuk disiplin karena penting bagi kehidupan. Salah satunya disiplin mematuhi rambu lalu lintas di jalan raya. Disiplin dalam berkendara bukan tentang supaya tidak ditilang tetapi perihal keselamatan untuk diri sendiri.

Dari sana aku belajar bahwa disiplin sangat penting.-Keselamatan dan keamanan diri kita sendiri... untuk orang lain juga. (Probolestari, 2011:13).

Amanat yang diambil dari naskah Jangan Pernah Menyesal Bertindak Jujur yaitu janganlah bersikap sombong. Jangan pernah memandang orang sebelah mata. Bisa jadi orang yang hidupnya berkecukupan ternyata mempunyai hati yang baik dan tidak menutup kemungkinan orang yang hidupnya serba ada malah mempunyai hati yang buruk. Tanamkan sikap jujur.

Ternyata berteman tanpa memandang derajat seseorang itu sangat membahagiakan...-sahabat yang begitu baik dan jujur,...-Aku benar-benar merasa bersyukur,... (Alexandra, 2011:21).

Amanat yang diambil dari naskah Disiplin Kunci Keberhasilan yaitu biasakan untuk disiplin. Karena kedisiplinan menjadi nilai utama jika ingin berhasil.

Ternyata, kalau ingin menjadi orang yang sukses, aku harus disiplin dalam segala hal. (Saputra, 2011:31).

Amanat yang diambil dari naskah Pensil Warna untuk Adik yaitu tetaplah berbuat baik walaupun dibalas dengan kejahatan. Biarkan orang lain menuduh selama kita merasa tidak melakukannya jangan takut untuk berkata jujur. Walaupun tidak punya apa-apa jangan sampai mencuri. Jujur yang mengungkap kebenaran itu.

Semua bisa dengan mudahnya menuduh, padahal mereka tidak tahu. Tetapi yang namanya kejujuran tidak akan pernah terkalahkan. (Irene, 2011:39).

Amanat yang diambil dari naskah Sepatu Kiki yaitu walaupun hidup sederhana dan serba berkecukupan, tetaplah bersyukur kepada Allah. Sesulit apapun hidup jangan memilih jalan yang salah misalnya dengan mencuri yang bukan hak kita. Tetaplah berbuat jujur. 
Walaupun ia hidup dengan sangat sederhana, tapi ia tidak pernah lupa bersyukur kepada Allah. Ia memiliki hati yang bersih dengan kejujuran. Aku yakin Allah sayang padanya. (Mardhotillah, 2011:100).

Amanat yang diambil dari naskah Ketidakjujuran Nanda yaitu jangan berbuat curang hanya karena ingin dipuji. Mungkin orang lain tidak akan tahu, tapi ada Allah yang maha mengetahui segala perbuatan makhluknya. Jika sudah ketahuan curang bukan hanya malu tapi rasa percaya orang lain akan hilang.

Sebenarnya aku jengkel dengan Nanda karena tidak mau berterus terang kalau cerpen yang dibuatnya itu hasil mencontek.-aku senang karena ia sudah mengaku terus terang... (Kristianti, 2011:113).

\section{Sudut Pandang}

Sudut pandang pada naskah Cerita Pohon Jati, Taat Membawa Selamat, Jangan Pernah Menyesal Bertindak Jujur, Disiplin Kunci Keberhasilan, Pensil Warna untuk Adik, dan Ketidakjujuran Nanda yaitu sudut pandang orang pertama tokoh utama. Ditandai dengan kata "aku" atau "saya”. Sedangkan pada naskah Sepatu Kiki yaitu sudut pandang orang pertama tokoh sampingan. Salah satu kutipan naskah yang memakai sudut padang orang pertama tokoh utama yaitu:

Aku terbangun, sinar matahari tepat menyinari wajahku-"selamat pagi, Bu Jati” kata burung kakak tua. (Sarita, 2011:2).

\section{Gaya Bahasa}

Gaya bahasa pada naskah Cerita Pohon Jati, Taat Membawa Selamat, Jangan Pernah Menyesal Bertindak Jujur, Disiplin Kunci Keberhasilan, Pensil Warna untuk Adik, Sepatu Kiki, dan Ketidakjujuran Nanda adalah bahasa lugas dan jelas sehingga mudah dibaca dan dipahami dari setiap kata yang disampaikan. Berikut kutipan yang menggambarkan gaya bahasa dari setiap cerpen.

"Kicauan burung terdengar merdu di telingaku-Hewan-hewan bersorak-sorai kegirangan" (Sarita, 2011:2-4).

“..kemarin sudah Mas isi penuh di pom bensin depan Kentucky Fried Chicken" (Probolestari, 2011:9-12).

"huh! Mana ada pencuri mau ngaku!... "Senyumku mulai mengembang di wajah ceriaku.bersamaan itulah hujan reda bergantikan pelangi riang yang menghiasi langit" (Alexandra, 2011:20-22).

"Sepatunya Bambang Pamungkas, bermerek Adidas, berwarna hitam dengan kombinasi merah dan putih" (Saputra, 2011:2829).

"Ekonomi keluargaku begitu mencekik leher.-tatapan mata yang tajam dan kata-kata yang menusuk", (Irene, 2011:34-37). 
"Adzan

maghrib

berkumandang.-Beribadah, berdzikir dan bersyukur atas nikmat Allah" (Mardhotillah, 2011:95-97).

"Cerita itu juga mengandung banyak nasihat yang dapat aku petik" (Kristianti, 2011:110).

\section{Analisis Unsur Ekstrinsik Kumpulan Naskah Cerpen LMCA Tahun 2011}

(Wellek, R., \& Warren, 2014) mengemukakan tiga paradigma pendekatan dalam sosiologi sastra, yaitu: (1) sosiologi pengarang; (2) sosiologi karya; dan (3) sosiologi pembaca juga dampak sosial karya sastra. Paradigma tersebut dapat dijelaskan dalam unsur ekstrinsik. Menurut (Kosasih, 2012) unsur ekstrinsik karya sastra ada tiga, yaitu:

\section{Latar Belakang Pengarang}

Naskah berjudul Cerita Pohon Jati dilatarbelakangi oleh pengalaman pengarang yang menyukai hutan terutama pada pohon jati. Pengarang membayangkan pohon jati seperti manusia sehingga pengarang tertarik membuat cerita genre fabel.

$$
\text { Naskah berjudul Taat }
$$

Membawa Selamat dilatarbelakangi oleh pengalaman pengarang yang merasa takut dengan jalan raya karena banyak kecelakaan motor. Pengarang mencari tahu tentang penyebab kecelakaan itu, ternyata karena kurang memperhatikan peraturan dan risiko yang dapat terjadi.
Naskah berjudul Jangan
Pernah Menyesal Bertindak Jujur dilatarbelakangi oleh pengalaman pengarang yang melihat banyaknya berita-berita pemalsuan, kejahatan, daan kebohongan. Pada naskah ini, pengarang menceritakan seseorang yang terlahir di keluarga berkecukupan tetapi angkuh. Memandang orang di bawahnya dengan sebelah mata sampai menuduh saat barangnya hilang. Tetapi dia sadar kemudian jujur dan mengakui kesalahannya.

Naskah berjudul Disiplin Kunci Keberhasilan dilatarbelakangi oleh pengarang yang mempunyai inspirasi dari buku berjudul Merah Putih di Old Traford yang menjelaskan pentingnya disiplin bagi pemain sepak bola.

Naskah berjudul Pensil Warna untuk Adik dilatarbelakangi oleh pengalaman pengarang pada saat kecil menginginkan pensil warna kemudian kakaknya membelikannya. Naskah berjudul Sepatu Kiki dilatarbelakangi oleh pengalaman pengarang saat melihat seorang anak pemulung memakai sepatu yang sudah berlubang. Sedangkan pengarang mempunyai banyak sepatu yang masih layak tetapi selalu meminta yang baru.

Cerita ini direkayasa dengan perbuatan mencuri karena dampak perekonomian. Naskah berjudul Ketidakjujuran Nanda dilatarbelakangi oleh pengarang yang mengangkat cerita yang mengandung kritik akan orang yang curang dengan menjiplak hasil karya orang lain. 


\section{Kondisi Sosial Budaya}

Kondisi sosial budaya pada kumpulan naskah LMCA tahun 2011 yang telah dianalisis ternyata tidak dijelaskan secara empiris, tetapi dapat dipahami dan diungkapkan melalui deskripsi sebagai berikut.

Kondisi sosial budaya pada naskah Cerita Pohon Jati yaitu masyarakat masih ada manusia yang menebang pohon secara liar padahal dilindungi oleh hukum.

Kondisi sosial budaya pada naskah Taat Membawa Selamat mengungkap bahwa melanggar peraturan lalu lintas masih menjadi budaya di masyarakat sehingga masih ada kecelakaan di jalan raya.

Kondisi sosial budaya pada naskah Jangan Pernah Menyesal Bertindak Jujur dapat dipahami bahwa pemalsuan seperti menuduh orang lain mencuri masih ada di kalangan masyarakat.

Kondisi sosial budaya pada naskah Disiplin Kunci Keberhasilan bahwa kebiasaan buruk yang masih banyak ditemukan pada diri seseorang yaitu tidak dispilin. Tidak sedikit orang yang gagal karena tidak bisa memanajemen waktu dengan baik. Padahal apapun profesi seseorang kedisiplinan merupakan kunci keberhasilan.

Kondisi sosial budaya pada naskah Pensil Warna untuk Adik hampir sama dengan kasus pada naskah Jangan Pernah Menyesal Bertindak Jujur. Naskah ini juga menceritakan anak yang hidup di jalanan mendapatkan diskriminasi dari temannya sampai dituduh mencuri padahal tidak dan membuat suasana panas. Menuduh sama saja melakukan kejahatan dan hal ini masih terjadi di masyarakat.

Kondisi sosial budaya pada naskah Sepatu Kiki yang dapat dirasakan juga di masyarakat bahwa banyak manusia yang membeli barang baru padahal barang yang ada masih layak pakai. Bahkan sampai dibuang. Padahal bisa jadi orang lain ada yang lebih membutuhkan. Misalnya saja, banyak anak yang putus karena tidak mempunyai alat dan seragam sekolah sampai mereka harus mencari uang melalui kegiatan memulung atau mengamen.

Kondisi sosial budaya pada naskah Ketidakjujuran Nanda dimana masih banyak orang melakukan kejahatan dengan berbuat curang menjiplak hasil karya orang lain hanya ingin terlihat bagus dan dipuji oleh orang lain. Hal itu masih dirasakan di masyarakat dan sangat meresahkan padahal bagaimanapun karya yang dibuat kalau dengan kejujuran akan bermanfaat bagi diri sendiri.

\section{Tempat Cerpen Dikarang}

Tempat dengan kondisi alam yang berbeda memengaruhi terhadap hasil karya. Misalnya cerita dibuat oleh pengarang yang tinggal di daerah agraris akan sedikit berbeda dengan cerita yang pengarangnya tinggal di daerah gurun. 
Kritik Sosial pada Kumpulan Naskah Cerpen LMCA Tahun 2011

Dari hasil kajian pada ketujuh naskah cerpen LMCA tahun 2011, menunjukkan bahwa adanya kritikan terhadap kehidupan sosial yang belum selaras dengan keadilan dan kejujuran. Terdapat enam kritik sosial di antaranya: kritik terhadap lingkungan, gender, ekonomi, pendidikan, kebiasaan/kebudayaan masyarakat, dan diskriminasi.

\section{Kritik Sosial Terhadap Lingkungan}

Kritik sosial pada naskah berjudul Cerita Pohon Jati mengungkap masalah lingkungan karena adanya perusakan alam dengan menebang pohon sembarangan oleh tangan-tangan jahil para oknum yang tidak bertanggung jawab. Diungkapkan pada kalimat berikut.

"manusia serakah itu pelakunya! Mereka menebang pohon untuk menambah kekayaan mereka," seru burung kakak tua.-Tidak tahukan mereka bahwa hutan yang ada di lereng gunung dilindungi. Tak tahukah mereka mereka bahwa pepohonan sangat berguna bagi mereka? Padahal pepohonan telah melindungi mereka dari banjir serta tanah longsor. Selain itu, pepohonan juga menyediakan oksigen bagi manusia agar tetap bersedia. (Sarita, 2011:2).

\section{Kritik Sosial Terhadap Gender}

Kritik sosial pada naskah berjudul Disiplin Kunci Keberhasilan dituangkan pada kalimat yang tersirat dimana membedakan kesetaraan gender antara perempuan dan laki-laki. Kalimat tersebut menegaskan bahwa kebiasaan tidak disiplin pada laki-laki adalah hal yang wajar. Padahal tidak semua laki-laki seperti yang disebutkan pada kalimat berikut. Karena watak yang menentukan disiplin atau tidaknya seseorang.

Wajar saja kalau aku tidak disiplin, karena aku anak laki-laki. (Saputra, 2011:26).

\section{Kritik Sosial Terhadap Ekonomi}

Kritik sosial pada naskah Sepatu Kiki mengandung kritik terhadap kehidupan Kiki yang kurang beruntung dalam hal ekonomi. Dalam kehidupan ini, ekonomi merupakan hal yang sensitif salah satunya uang. Berbagai cara bisa dilakukan orang lain untuk mendapatkan uang sekalipun itu jalan haram. Salah satunya mencuri. Kondisi ekonomi yang buruk memaksa seseorang untuk berbuat tidak semestinya. Dan benar saja bahwa ekonomi yang buruk dapat membuat seseorang berbuat kejahatan seperti mencuri, merampok, dan lain-lain. Tentunya ada alasan di balik seseorang melakukan hal tersebut. Tetapi, mencuri tetaplah mencuri. Karena sesulit apapun kehidupan ekonomi jangan sampai mencuri, lebih baik mencari pekerjaan yang halal.

Seringkali dia ditegur guru kelasnya karena belum membayar uang sekolah.-entah terpikir 
darimana, ia mendekati tas wali kelasnya...-ia membuka bagian depan tas itu, memasukkan tangannya ke dalamnya...-ia mengambil uang 10.000 rupiah dari tas wali kelasnya."aku sudah berdosa, mencuri uang... tapi apa yang bisa aku lakukan untuk memenuhi keinginan adikku?”-“saya telah mencuri, Bu. Saya mohon, maafkan saya. Saya hanya ingin membeli es krim untuk kedua adik saya. Ini uang ibu saya kembalikan lagi”. (Mardhotillah, 2011:96-99).

\section{Kritik Sosial Terhadap Pendidikan}

Kritik sosial pada naskah Ketidakjujuran Nanda masih mengkritik pendidikan yang mana siswa berani melakukan kecurangan dengan menyontek hanya untuk mendapatkan pujian dan nilai yang bagus. Padahal kejujuran lebih penting. Hal ini karena masih menerapkannya pandangan bahwa nilai lebih penting dari sebuah kejujuran. Makanya, perlu diperhatikan lagi bagaimana seseorang jika membuat karya terutama dari prosesnya.

"cerpen tadi karanganmu sendiri, Nda?"-"iya, benar. bagus kan?.."-"sepertinya cerpen itu pernah aku dengar... di Majalah Ceria".- "ah, tidak mungkin.."-“Nda, cerpen yang kamu baca kemarin itu ternyata ada di majalah ini".-"wah, kalau demikian berarti Nanda telah berbuat tidak jujur. Nanda telah mencontek hasil karya orang lain"-“maafkan aku,.. aku mengakui bahwa cerpen yang aku buat kemarin memang hasil contekan dari Majalah Ceria. Aku pikir temanteman tidak ada yang tahu”. (Kristianti, 2011: 112-113).

\section{Kritik Sosial Terhadap Kebiasaan/Kebudayaan Masyarakat}

Kritik sosial pada naskah berjudul Taat Membawa Selamat mengungkap masalah yang masih menjadi kebiasaan atau budaya di masyarakat. Masalah tersebut mengenai pelanggaran tata tertib lalu lintas. Masih banyak orang berkendara tanpa memperhatikan syarat berkendara dengan benar. Poin penting bahwa disiplin dalam berkendara bukan perihal supaya tidak ditilang tetapi perihal keselamatan untuk diri sendiri dan orang lain.

"Mas, kok kemarin aku lihat motornya Mas Bayu spionnya hanya sebelah kanan yang dipasang. Memangnya itu sudah benar?"-"itu pelanggaran, Sen..."-“coba

bayangkan, Sen. Anak-anak remaja sekarang kan banyak yang suka ngebut. Mereka saling menyalip".pengendara motor itulah yang salah. Jelas-jelas lampu merah tapi mereka menerobos...-gara-gara pengendara motor yang melanggar lampu merah, banyak orang terkena masalah. (Probolestari, 2011: 10-12).

\section{Kritik Sosial Terhadap Sikap Diskriminasi \\ Kritik sosial pada naskah berjudul Jangan Pernah Menyesal Bertindak Jujur mengungkap sikap diskriminasi terhadap kehidupan orang}


lain, yang mana dalam cerita tersebut memandang derajat seseorang sampai menuduh mencuri. Padahal derajat manusia itu sama di hadapan Tuhan Yang Maha Esa.

"sudahlah, Sya! Lagi pula mereka kan memang orang miskin! Mereka itu enggak ngerti apa-apa dan enggak selevel sengan kita! Huhu! Kampung!".-"hei orang kampung! Udah deh, nggak usah sok membela diri!".-"'hei anak kampung, kamu tidak pantas tinggal disini!Kamu itu pantasnya tinggal di tempat sampah!..." (Alexandra, 2011:17-18).

Kritik sosial pada naskah berjudul Pensil Warna untuk Adik menggambarkan perilaku diskriminasi terhadap teman sendiri hanya karena hidupnya berkecukupan sehingga mengejek sampai menuduh mencuri.

"hei, ya mau apa? Mau beli buku, apa beli pensil warna? Apa mau mencuri? Gak punya uang aja sok liat-liat di koperasi, hwahaha!""beli? Emang kamu punya uang? Dasar tukang nyolong!" (Irene, 2011:35-37).

\section{SIMPULAN}

Berdasarkan hasil kajian secara struktural, setiap naskah cerpen memiliki unsur intrinsik (alur, tokoh, latar, tema, amanat, sudut pandang, gaya bahasa) dan unsur ekstrinsik (latar belakang pengarang, kondisi sosial budaya, tempat cerpen dikarang) yang berbeda-beda. Dalam penelitian ini menemukan empat jenis latar sebagai pembaharuan yaitu, latar tempat berdasarkan arah mata angin, latar waktu berdasarkan posisi tata surya (bulan), latar waktu berdasarkan iklim, dan latar waktu berdasarkan waktu ibadah salat. Unsur ekstrinsik memengaruhi dasar terciptanya setiap naskah cerpen.

Hal itu dilihat dari pengalaman pengarang yang merefleksikan kehidupannya melalui karya sastra tersebut. Sedangkan hasil kajian secara sosiologi, ketujuh naskah cerpen sangat menarik karena mengungkap kritik sosial sebagai wujud kegelisahan dan keprihatinan pengarang melihat kehidupan saat ini. Ada enam masalah sosial yang dikritik yaitu masalah lingkungan, gender, ekonomi, pendidikan, kebiasaan/kebudayaan masyarakat, dan sikap diskriminasi. Di antara keenam kritik sosial yang paling dominan yaitu kritik terhadap sikap diskriminasi.

Hasil analisis tersebut mengungkap temuan dari pengalaman pengarang mengkritik sikap manusia yang menyimpang. Misalnya penebangan pohon secara liar, melakukan pencurian karena ekonomi yang buruk, kebiasaan melanggar peraturan yang masih disepelekan, bahkan sikap diskriminasi masih sering ditemukan di kehidupan nyata.

\section{REFERENSI}

Ardiyanti, H. (2017). Kritik Sosial Dalam Cerpen Sakura No Kinoshita $\mathrm{Ni} W a$ (桜の樹の下に は) Karya Motojiro Kajii Kajian Sosiologi Sastra. Skripsi Dipublikasikan. Universitas 
Diponegoro.

Creswell, J. W. (2015). Qualitative Inquiry \& Research Design: Chosing Among Five Approaches, Third Edition. (3rd ed.). CV: Sage.

Damono, S. D. (2010). Sosiologi Sastra: Pengantar Ringkas (Edisi Baru). Ciputat: Editum.

Effendi, S. (1973). Bimbingan Apresiasi Puisi. Flores: Nusa Indah.

Kosasih, E. (2012). Dasar-dasar Keterampilan Bersastra. Bandung: Yrama Widya.

Kurniawan, H. (2013). Sastra Anak dalam kajian strukturalisme, sosiolohi, semiotika, hingga penlisan artikel kreatif. Yogyakarta: Graha Ilmu.

Lestari, S., Rakhmawati, A., \& Rohmadi, M. (2016). Analisis Unsur Intrinsik Dan Ekstrinsik Pada Kumpulan Cerpen Pilihan Kompas $2014 \quad$ Serta Relevansinya Sebagai Materi Pembelajaran Sastra Di Sekolah Menengah Atas. BASASTRA Jurnal Penelitian Bahasa, Sastra Indonesia Dan Pengajarannya, 4(1), 183-202.

Miles, M. B. \& Huberman, A, M. (1984). Analisis Data Kualitatif. Terjemahan oleh Tjetjep Rohendi Rohidi. Jakarta: Penerbit Universitas Indonesia.

Moleong, L. J. (2014). Metodologi Penelitian Kualitatif. Edisi Revisi. Bandung: Remaja Rosda Kerja.

Nandasari, V., \& Hasanah, D. U. (2020). Kritik Sosial Dan NilaiNilai Pendidikan Karakter Dalam Novel Orang-Orang Biasa Karya Andrea Hirata. ALAYASASTRA, 16(2), 218-236. https://doi.org/10.36567/aly.v16i 2.664

Nurgiyantoro, B. (2013). Penilaian Pembelajaran Bahasa Berbasis Kompetensi. Yogyakarta: Badan Percetakan Fakultas Ekonomi Universitas Negeri Yogyakarta.

Pratiwi, Y. I., Harun, M., \& Herman, R. (2018). Kritik Sosial dalam Novel Tanah Surga Merah Karya Arafat Nur. Jurnal Ilmiah Mahasiswa Pendidikan Bahasa Dan Sastra Indonesia, 3(3), 281293.

Puspita, A. C., Suwandi, S., \& Hastuti, S. (2018). Kritik Sosial dan Nilai Moral dalam Novel "Negeri di Ujung Tanduk" Karya Tere Liye. Indonesian Language Education and Literature, 4(1), 11. https://doi.org/10.24235/ileal.v4i 1.1956

Rahmanto, B. (1988). Metode Pengajaran Sastra. Yogyakarta: Kanisius.

Ratna, N. K. S. U. (2006). Teori, Metode, dan Teknik Penelitian Sastra. Yogyakarta: Pustaka Pelajar.

Ratna, N. K. S. U. (2014). Peranan Karya Sastra, Seni, dan Budaya dalam Pendidikan Karakter. Yogyakarta: Pustaka Pelajar.

Rokhmansyah, A. (2014). Studi dan Pengkajian Sastra: Perkenalan Awal Terhadap Ilmu Sastra. Yogyakarta: Graha Ilmu.

Saini, K. M. (1986). Protes Sosial dalam Sastra. Bandung: Angkasa.

Sarumpaet, R. K. T. (2010). Pedoman Penelitian Sastra Anak. In Journal of Chemical Information and Modeling (Vol. 53, Issue 9).

Strauss, A., \& C. J. (1998). Basic of Qualitative Research: Grounded 
Theory Procedurs and teqniques (edisi ke-2).

Suandi, I. . N. (2008). Pengantar Metodologi Penelitian Bahasa. Singaraja: Universitas Pendidikan Ganesha.

Sutopo, H. B. (2002). Metodologi Penelitian Kualitatif: Teori dan Aplikasinya Dalam Penelitian. Surakarta: Sebelas Maret University Press.

Swingewood, Al., \& Laurenson, D. (1972). The Sociology of Literature. London: Granada Publishing Limited.

Teeuw, A. (1984). Sastra dan Ilmu Sastra. Jakarta: Pustaka Jaya.

Tube, B. (2018). Kritik Sosial dan Nilai-nilai Pendidikan Novel Lembata Karya F. Rahardi. PROLITERA Jurnal Penelitian Pendidikan, Bahasa, Sastra, Dan
Budaya, 1(1).

Wellek, R., \& Warren, A. (1989). Teori Kesusastraan (Terjemahan Melani Budianta). Jakarta: PT. Gramedia.

Wellek, R., \& Warren, A. (2014). Teori Kesusastraan. Jakarta: PT Gramedia.

Witakania. (2008). Aspek Psikopedagogik dalam Sastra Anak. [Online]. Diakses dari: https://www.academia.edu/2036 6224/ASPEK_PSIKOPEDAGO GIK_DALAM_SASTRA_ANA $\mathrm{K}$ ?auto=download

Yulianto, A. (2017). Kritik Sosial Dalam Dua Cerita Pendek Karya Pengarang Kalimantan Selatan Social. Jurnal Bebasan, 4(2), 121-132. 